University of South Florida

DIGITAL COMMONS

Digital Commons @ University of

@ UNIVERSITY OF SOUTH FLORIDA

South Florida

Integrative Biology Faculty and Staff

Publications

Integrative Biology

1983

\title{
Area-Related Species Richness: The Uses of Ecological and Paleontological Data
}

\author{
Earl D. McCoy \\ University of South Florida, earlmccoy@usf.edu \\ Jorge R. Rey \\ University of Florida
}

Follow this and additional works at: https://digitalcommons.usf.edu/bin_facpub

Part of the Medical Sciences Commons

\section{Scholar Commons Citation}

McCoy, Earl D. and Rey, Jorge R., "Area-Related Species Richness: The Uses of Ecological and Paleontological Data" (1983). Integrative Biology Faculty and Staff Publications. 4.

https://digitalcommons.usf.edu/bin_facpub/4

This Response or Comment is brought to you for free and open access by the Integrative Biology at Digital Commons @ University of South Florida. It has been accepted for inclusion in Integrative Biology Faculty and Staff Publications by an authorized administrator of Digital Commons @ University of South Florida. For more information, please contact digitalcommons@usf.edu. 


\section{NOTES AND COMMENTS}

\section{AREA-RELATED SPECIES RICHNESS: THE USES OF ECOLOGICAL AND PALEONTOLOGICAL DATA}

What might be the most important reason for variations in the sizes of pest faunas accrued by plants? We have singled out the areal range of the host as the single best predictor (see Rey et al. 1981, 1982 and included references), and have noted that other proximal ecological variables, such as plant architecture (Strong and Levin 1979) and geographic location (McCoy and Rey 1983), are secondarily important. We have found no reason to support time per se as a predictor of the sizes of herbivorous pest faunas.

When we first proposed these ideas, some of them almost 10 years ago, they were highly controversial. If all had proceeded as usual in ecology, the intervening years should have seen them either die out or enter the ecological mainstream. Instead, they remain controversial.

We will not detail the methods we have used nor attempt to justify them, nor even present our philosophy concerning the ecologist's role in studying long-term processes, for we have done so in great detail elsewhere (Rey et al. 1981). We will reply specifically to certain aspects of Boucot's (1983) note.

Boucot (1983) states: "Rey et al. (1981) and Strong et al. (1977) appear to make the assumption that host-parasite relations are analogous to island-organism relations"' (p. 294). A quotation taken from our earlier paper (Rey et al. 1981) makes our position clear: "We do not use the host island metaphor because the careless or casual reader might infer that we had implied more than a simple correlation between host range and species number"' (p. 613). (Gilbert [1980] should not have included references to our work in his othewise excellent critique of those who accepted too readily the theory of island biogeography. He realizes this and has removed the references from all reprints [personal communication]).

Throughout his note, Boucot (1983) seems to want us to conform to his definition of "community" (basically, the regular recurrence of associations over long time spans). He says: "Paleontological data are the only reliable source for obtaining the relative and absolute age of extant communities ..." (p. 297) and “. . . communities . . . remain static through long intervals of evolutionary time (commonly . . . fives and tens of millions of years. . .)" (pp. 294-295). Of course these statements are true for the paleontological "communities" that Boucot (1983) envisions; but are they appropriate for the associations of herbivores that we have examined? We think not and we therefore fail to see how Boucot (1983) expects us to meet his challenge (p. 294) to provide evidence from the study of associated communities to support the assumption that similar-sized areas represent ecologically comparable entities. In fact, given his paleontological definition of "community," we wonder if the challenge can be met. Yet even if we were to employ an ecological definition of "community," we would not be much further

Am. Nat. 1983. Vol. 122, pp. 567-569.

(C) 1983 by The University of Chicago. $0003-0147 / 83 / 2204-0020 \$ 02.00$. All rights reserved. 
ahead, for we could not then deal with his phrases such as "community character" and "associated communities."

If, as he suggests in the latter part of his note, Boucot thinks we should have introduced evidence that coevolution on human time scale has occurred between the introduced species and their native pests, we can only answer, "Why should we?" Coevolution is only one of many forces that may have an influence on community structure and dynamics and is extremely difficult to document, even for a single species pair at a single locality (Janzen 1980). A demand to demonstrate coevolution among whole faunas worldwide is unrealistic. Why not demand also that we demonstrate the effects of competition, predation, parasitism, disease, the physical environment, life history tactics, natural disasters, plant chemistry, chance, and others on the patterns of species richness of every host plant on every region that we examined? We reiterate Janzen's (1980) plea to remove the meaning of coevolution from synonymy of usage with "interaction," "symbioses," "mutualism," and "animal-plant interaction" to preserve the usefulness of the concept of coevolution in biology.

Boucot's (1983) premise that monocultures will disintegrate without man's intervention is appealing, but is far from factual. Nevertheless, consider it true for now; even in the extreme case, that in which the host disappears completely from a location to which it had been introduced, we would predict there would be no associated herbivores in that location. If the postcultivation loss of area were less severe, we would predict commensurately curtailed loss of herbivore species. The fact that crops dealt with in our papers are subjected to mechanized monoculture in some locations and laissez-faire agriculture in others, makes our results all the more significant. Also important, as we have pointed out often, is the fact that native locations of the plant species do not appear unusual in the numbers of species of herbivores accrued, compared to nonnative locations. Finally, studies we have cited previously (Rey et al. 1981) demonstrate that numbers of species of associated herbivores may be predicted by areal coverage of the host even for nonagricultural plants.

Frankly, we are surprised that Boucot, whose significant findings agree with ours, basically, would go to such lengths to criticize our methods. What is to be gained? If it is the promotion of paleontological hegemony in these matters, then we think the attempt has failed. Apart from the arguments presented above, we also can point to the fact that paleontologists are as limited by their methods as are ecologists. Just as ecologists may not be able to determine the exact age of a specific community, as Boucot (1983) proposes, paleontologists may not be able to determine how fast it arose. To put things in perspective, the time scale employed in our research is included within one of those veiled intervals in the fossil record where one "community" becomes extinct and another replaces it without any apparent transition. While the paleontologist may marval that all of this has come about in an evolutionary blink-of-the-eye, the time is an ecological eternity. Recall that our research has dealt with time spans of a few hundred years, not a few hundred thousand. For such recent insect assemblages the ecologist can indeed find ways to ferret out their relative or absolute ages (see Strong et al. 1977). 
LITERATURE CITED

Boucot, A. J. 1983. Area-dependent-richness hypotheses and rates of parasite/pest evolution. Am. Nat. 121:294-300.

Gilbert, F. S. 1980. The equilibrium theory of island biogeography: fact or fiction? J. Biogeogr. 7:209235.

Janzen, D. H. 1980. When is it coevolution? Evolution 34:611-612.

McCoy, E. D., and J. R. Rey. 1983. the biogeography of herbivorous arthropods: species accrual on tropical crops. Ecol. Entomol. (in press).

Rey, J. R., E. D. McCoy, and D. R. Strong. 1981. Herbivore pests, habitat islands, and the speciesarea relation. Am. Nat. 117:611-622.

Rey, J. R., D. R. Strong, and E. D. McCoy. 1982. On overinterpretation of the species-area relationship. Am. Nat. 119:741-743.

Strong, D. R., and D. A. Levin. 1979. Species richness of plant parasites and growth form of their hosts. Am. Nat. 114:1-22.

Strong, D. R., E. D. McCoy, and J. R. Rey. 1977. Time and the number of herbivore species: the pests of sugarcane. Ecology 58:167-175.

EARL D. McCoY

Department of Biology

University OF SOUTH Florida

TAMPA, FLORIDA 33620

UNIVERSITY OF FLORIDA - IFAS

JORGE R. REY

Florida Medical Entomology Laboratory

P. O. Box 520,

Vero Beach, Florida, 32961

Submitted August 13, 1982; Accepted March 31, 1983 